\title{
PHASELIS \\ On the Exercise of Coastal Control through Observation and Long Distance Communica- tion Systems in Seljuk Territory in the XIIIth Century
}

\author{
XIII. Yüzyıl Selçuklu Topraklarında Gözetlemeye Dayalı Kıyı \\ Kontrolü ve Uzun Mesafe iletişim Sistemleri Üzerine
}

T. M. P. DUGGAN - Mehmet Emin ŞEN

open 2 access journals

PHASELIS: Disiplinlerarası Akdeniz Araştırmaları Dergisi'nde bulunan içeriklerin tümü kullanıcılara açık, serbestçe/ücretsiz "açık erişimli" bir dergidir. Kullanıcılar, yayıncıdan ve yazar(lar)dan izin almaksızın, dergideki makaleleri tam metin olarak okuyabilir, indirebilir, dağıtabilir, makalelerin çıktısını alabilir ve kaynak göstererek makalelere bağlantı verebilir.

PHASELIS: Disiplinlerarası Akdeniz Araştırmaları Dergisi uluslararası hakemli elektronik (online) bir dergi olup değerlendirme süreci biten makaleler derginin web sitesinde (journal.phaselis.org) yıl boyunca ilgili sayının içinde (Volume II: Ocak-Aralık 2016) yayımlanır. Aralık ayı sonunda ilgili yıla ait sayı tamamlanır.

Dergide yayımlanan eserlerin sorumluluğu yazarlarına aittir. Distance Communication Systems in Seljuk Territory in the XIIIth Century". Phaselis II (2016) 117. DOI: $10.18367 /$ Pha.16002 Kabul Tarihi: 20.03.2016 | Online Yayın Tarihi: 1.04.2016

Editörya Phaselis Research Project www.phaselis.org 


\title{
On the Exercise of Coastal Control through Observation and Long Distance Communication Systems in Seljuk Territory in the XIII ${ }^{\text {th }}$ Century
}

\author{
XIII. Yüzyıl Selçuklu Topraklarında Gözetlemeye Dayalı Kıyı Kontrolü ve Uzun Mesafe \\ iletişim Sistemleri Üzerine
}

\section{T. M. P. DUGGAN* Mehmet Emin ŞEN**}

\begin{abstract}
The exercise of coastal control in Rūm Seljuk territory in the XIII ${ }^{\text {th }}$ century, on both MediterraneanWhite and Black Sea coastlines is almost entirely unaddressed in the modern literature, although the title of the responsible official, when not directly administered by the Sultān, is recorded, emir-i sevahil, Emir of the Coastlines, and after 1250, malik al-sawahil, Ruler of the Coastlines.

The mountainous, indented S.W. coastline of the Sultanate by 1226 extended for more than $600 \mathrm{~km}$, Dalaman to near Silifke, yet rapid communications were essential to the exercise of effective state control. How did timely information reach the sultān in his peregrinations and campaigns - news of the passage of a Crusader or pirate fleet, an uprising, or the arrival of envoys?

This brief article outlines the communication systems that would have been employed, relates them to "The Second Sulaymān", the laqubawarded to Rūm Seljuk Sultans from 1205 to 1247, and suggests the manār tower immediately to the west of Şarâb-salâr han, $15 \mathrm{~km}$ west of Alanya was a station in this network, signals from this structure being clearly visible from the castle of 'Ala'iyya-Alanya lying to its East.
\end{abstract}

Keywords: Rūm Seljuk Sultanate $\cdot$ Communications · Manar · Jinn

Öz: XIII. yüzyılda Rum Selçuklu karasularındaki hem Akdeniz hem de Karadeniz kıyı kontrolü uygulamasına, modern literatürde hemen hemen hiç değinilmemiştir; ancak doğrudan Sultan tarafından idare edilmediği zamanlar, bu işten sorumlu memurun unvanı, "Emir al-Savahil", "Sahillerin Emiri" olarak ve 1250 yilından sonra ise bu unvan, "Malik al-Savahil", "Kıyıların Maliki" olarak kayıtlarda geçiyordu.

1226 yılına kadar Sultanlığın dağıık ve girintili-çıııntılı Güney Batı sahili, 600 km'den daha fazla uzundu. Dalaman'dan Silifke yakınlarına kadar. Bununla birlikte etkili bir devlet kontrolü için hızlı haberleşme zaruriydi. Haçılıarın veya korsan filolarının geçişi, bir ayaklanma veya bir elçinin gelişi nasıl oluyordu da anlık bir bilgi olarak gezide veya seferde olan Sultana ulaştırılıyordu?

Bu kısa makale, kullanılmış olan haberleşme sistemini özetlemektedir ve 1205 tarihinden 1247 tarihine kadarki Rum Selçuk Sultanlarına ikinci Süleyman lakabı verilmiştir; bu durum da Şarab-salar Han'ın hemen batısında, Alanya'nın 15 km batısındaki manar kulesinin bu ağın bir istasyonu olduğunu ön görmektedir. Bu yapıdan gönderilen işaretler, 'Ala'iyya-Alanya'nın doğusunda uzanan kaleden net bir şekilde görülebiliyordu.

Anahtar Sözcükler: Rum Selçuklu Sultanlığı · Haberleşme · Manar · Cin

* Öğr. Gör., Akdeniz University, Mediterranean Civilisations Research Institute, Antalya. tmpduggan@yahoo.com

An earlier version of this paper was presented at the $1^{\text {st }}$ International Mediterranean Studies Colloquium, H.E.P. University, Alanya, $4^{\text {th }}-5^{\text {th }}$ April, 2015.

** Doç. Dr., Akdeniz University, Mediterranean Civilisations Research Institute, Antalya.

mehmeteminsentarih@gmail.com 
The exercise of coastal control in Rūm Seljuk territory in the XIII ${ }^{\text {th }}$ century, along both the Mediterranean and Black Sea coastlines has remained a subject almost entirely unaddressed in the modern literature, although the title of the responsible official, when these coastlines were not directly administered by the Rūm Seljuk Sultan, is recorded, emir al-sawahil, Emir of the Coastlines, and usually after 1250, malik al-sawahil, Ruler of the Coastlines ${ }^{1}$.

It is however evident that the Sultan needed to be informed, wherever he was, in respect to the muhabereler, the reports-news, from both the coastlines, not only because he had the title sultān al-barr wal-bahr and, following the re-conquest of Antalya in 1216, the title sultān al-barr wal-bahrain (Sultan of the land and the two seas - the Black and the White-Mediterranean), but because, in this period of Latin Catholic Crusade, he needed news of the passage of fleets and raiders, he needed to be informed if there was a maritime assault or a maritime invasion launched by Crusaders upon his territory from a passing Crusader fleet, news of the presence of pirates-corsairs, news of the arrival by sea of envoys from Muslim or Christian states, of any repeat of the 1212 uprising in Antalya etc., intelligence that required expeditious delivery, not least because of the proximity of the Latin Lusignan Crusader state of Cyprus, together with its Templar and Hospitaller Order of St. John of Jerusalem forces, lying less than $60 \mathrm{~km}$ off the nearest point of the Rūm Seljuk Mediterranean coast.

Given the length of the rugged, mountainous and indented coastline along the southwestern border of the Sultanate, which by 1226 extended over a distance as the crow flies of more than $600 \mathrm{~km}$, from Dalaman to near Silifke (for the eastern part after 1225, Fig. 15), and, of the Sultan's need to be informed, essential to the exercise of effective state control, this coastal terrain backed by the Taurus Mountains, presented serious problems in terms of the time taken in the conveying of information rapidly from place to place. For example, if only a mounted courier system were employed, with, for example, the courier carrying the news of a Crusader fleet passing Patara, by the time the mounted courier had reached Antalya, the Crusader fleet could have sailed along the coastline and reached and sacked the city before the messenger had arrived ${ }^{2}$.

It was necessary to exercise effective coastal control through observation and secure communication in practice, and this was also articulated in the correspondence concerning mutual obligations to be entered into by both the Rūm Seljuk state and that of Lusignan Cyprus in their treaty negotiations in the second decade of the XIII ${ }^{\text {th }}$ century. An obligation by the Seljuk Sultanate to maintain a coastal watch to combat piracy is implicit in the exchange of letters concerning a treaty between Sultan 'Izz al-Dīn Kaykavas I (1211-20) and Hugh I of Cyprus (120518) with a letter dated Sept. 1216, from Sultan 'Izz al-Dīn to King Hugh of Cyprus containing the following passage:

1 For example, see: Turan 1988, 152; Özcan 2005, 83. It is unclear as to if these posts were duplicated, one Emir for the White-Mediterranean, another for the Black Sea, or were combined in the person of a single Emir and if the title Emir was inflated into Malik or if both posts were occupied at the same time in the second half of the XIII ${ }^{\text {th }}$ century as, although an inscription dated A.H. 676 - from June 1277 onwards, records Badr ud-Dīn was emir al-sawahil, by 1281 he is recorded in another inscription as malik al-sawahil, Lloyd - Storm Rice 1958, 63. The relative status of the emir of the coastlines at Antalya and that at Sinope, ie. if there were two emir who carried this title at the same time, one responsible for the Black Sea, the other the White or Mediterranean, and that between the emir and the malik of the coastlines over the course of the XIII ${ }^{\text {th }}$ century remains today unclear.

2 Duggan 2014; forth. a. 
"If by chance it happens that corsair vessels or ships of any kind inflict damage on any of the lands of his royal highness either by land or sea, and they happen to be passing by my territories loaded with the booty they have acquired, my people shall at once seize and confiscate all of them and they shall arrange for them (ship and booty) as well as for their captured owners to be returned to his eminence the King of Cyprus; the aforementioned King is expected to act likewise in similar cases" ${ }^{\prime 3}$.

The passage reading, "passing by my territories... my people shall at once seize and confiscate all of them", clearly implies, firstly, that a coastal watch was maintained along the coastline and at all the ports along the Mediterranean coastline of the Sultanate in 1216, the ports of Lycia, Patara, Meğri, Myra-Stamira, Finike, Olympos etc., an area recognized as Seljuk territory in the Seljuk-East Roman treaty of 1211, as well as at the main port of Antalya re-conquered in 1216, were under Seljuk state control. Secondly, that the Seljuk forces stationed in these ports were sufficient to seize corsair craft passing along the coastline, meaning that there were numbers of Seljuk troops and war-craft stationed in these ports by the second decade of the XIII ${ }^{\text {th }}$ century, not just in the port of Antalya, and, that they were linked by an observation and communications system that enabled them to co-ordinate and act "at once".

It is known that the main Seljuk Mediterranean naval base was at Antalya, another, after 1221 at 'Ala'iyya-Alanya, that there was a Rüm Seljuk reis ul'bahr ${ }^{4}$ and the emir-i sevahil, Emir of the Coastlines, and after 1250, the malik al-sawahil, Ruler of the Coastlines, but the question is, how did timely information reach these bases and emirs, and most importantly reach the sultan in the course of his peregrinations and campaigns - conveying the news of the passage of a Crusader, or a pirate fleet, of a potential landing of hostile forces, news of a revolt against Seljuk rule, as in Antalya in 1212, or relating the arrival in Rūm Seljuk territory of a ulak-intelligencer/envoy at a port distant from these centres and the sultan? And through what method(s) did the sultan communicate the necessary order-instructions-reply?

\section{Sulaymān b. Dāwūd/Süleyman/Solomon son of David and the Second Sulāyman}

The First Sulaymān, that is the Prophet Sulaymān b. Dāwūd/Solomon son of David, in the Book of the Word, in the Holy Koran, the primary source, is remarked upon for the wisdom that the Almighty bestowed upon him, for his control over the winds ${ }^{5}$, over armies of men, animals, birds and $\mathrm{jinn}^{6}$, and with the ability to understand the languages of the temporal world, from ants $^{7}$, birds $s^{8}$ and people ${ }^{9}$ to the jinn ${ }^{10}$. The Prophet Sulaymān was informed of what was happening in the worlds of people, creatures and jinn, and stood at the centre of, and was the recipient of communications, including the Divine and the secret, and he sent letters through

\footnotetext{
Savvides 1981, 144; see also Turan 1988, 109-119.

Bibi II. 127.

Surat Şād 38. 36 "So We subjected to him the wind blowing by his command, gently, wherever he directed". Surat An-Naml 27. 17.

Surat An-Naml 27. 18-19 "So [Solomon] smiled, amused at her [the ant's] speech".

Surat An-Naml 27. 16 "And Solomon inherited David. He said, "O people, we have been taught the language of birds, and we have been given from all things. Indeed, this is evident bounty"; 27. 20-27 "And he took attendance of the birds and said, "Why do I not see the hoopoe - or is he among the absent?".

Surat An-Naml 27. 17.

10 Surat An-Naml 27. 17; 27. 38 "[Solomon] said, "O assembly [of jinn], which of you will bring me her throne before they come to me in submission?".
} 
the air ${ }^{11}$, and was able to exercise the execution of his instructions over vast distances within the blink of an eye ${ }^{12}$.

The Prophet Sulaymān, "endowed with all good things"13, "and rightly guided"14, provided the authoritative model of the wise and informed temporal ruler at the centre of a superb hyper speed communication-intelligence system, from al-Quds-Jerusalem to Yemen and back, in the blink of an eye, the work, like other marvels, of the Believing Jinn and it seems the Prophet Sulaymān b. Dāwūd was regarded as the model figure for Abbāsid period communications and, within this context the Prophet Sulaymān was not only associated with control over the Jinn of the Land, Sea and of the Air, of the communication by the Jinn that travelled at or faster than the speed of light, for example from Jerusalem to Yemen and back, within the blink of an eye as related in the Holy Koran Surah Al-Naml 27: 39-40:

"A stalwart of the Jinn said: I will bring it (the throne of the Queen of Sheba-Belkis) to thee before thou canst rise from thy place. Lo! I verily am strong and trusty for such work. 40. One with whom was knowledge of the scriptures (a Believing Jinn) said: I will bring it thee before thy gaze returneth unto thee. And when he saw it set in his presence (Solomon) said: This is of the bounty of my Lord..." that is a distance in a straight line one way of 1267 miles / 2039.04 km, a return journey of 2534 miles / $4076 \mathrm{~km}$ in less than the blink of an eye; as also being associated with the creature that is termed a 'griffon' which is also depicted on Seljuk ceramic vessels, as elsewhere ${ }^{15}$ and freestanding in bronze ${ }^{16}$, which is a creature that is described by the contemporary Muhyīddīn Ibn 'Arabī (1165-1240 A.D.) as being, "potentially in existence, but not existing, and which is a secret known only to the Prophet Sulaymān"17, hence associating the depictions of the 'griffon', like those of the Jinn of the Land and Air and Sea, re: Surat Al-Anbiyā' 21:82, with the Prophet Sulaymān; as also with the famous seal-shamsa of 6 or 8 points associated with this Prophet (the finest example of which is perhaps in cut-tile mosaic in the apex of the dome of the Great Mosque of Malatya with the word 'Muhammad' repeated 6 times in Kufi script one on each of the 6 arms of the seal. Thus thereby repeating in visual form the lines from Hakim Sana'i's (d. 1131) Dıwan:

"I asked the wind: "Why do you serve Solomon?" It said: "Because Ahmad's name is engraved on his seal"18; but also because the Prophet Sulaymān is also recorded in the Islamic tradition related by 'Umar b. Shabbah al-Numayī as possessing a most important mirror - mir'āh, said to have originally been given by the Almighty to Adam, enabling him see whatever he wished on earth:

"Issā b. 'Abd-Allah told me: My uncle 'Abd-Allah b. 'Umar told me that 'Alī - peace be upon him - said, 'When Adam was brought down from Paradise, Allah raised him

11 Surat An-Naml 27. 28 "Take this letter of mine and deliver it to them. Then leave them and see what [answer] they will return".

12 Surat Al-Naml 27. 40 "Said one who had knowledge from the Scripture, "I will bring it to you before your glance returns to you".

13 Surat Al-Naml 27. 16.

14 Surat al-An'an 6. 84.

15 Examples include those produced under the Fatimids in the $\mathrm{X}^{\text {th }}-\mathrm{XI}^{\text {th }}$ century, e.g. in lustre Ettinghausen Graber 1994, fig. 157.

16 Ettinghausen - Graber 1994, fig. 188.

17 Elmore 1999, 80 n. 68.

18 Cited, Schimmel 2001, 191. 
to the top of (Mount) Abū Qubays and (gradually) lifted the whole of the earth for him so he could see it. Then he said (to him), 'All this belongs to you and your children.' Adam said, 'O Lord, how may I know what is in it?' So he created the stars for him and said, "If you see such and such a star, it means so and so.'" My uncle, ('Abd-Allah b. 'Umar) said, "Thus Adam used to know such things by means of the stars. Then that became too difficult for him; accordingly he complained about alMada'in to his Lord. So he sent him a mirror (mir'āh) from heaven through which he could see whatever he wished on earth ${ }^{19}$. When Adam died, a devil called Faqtash sought out the mirror, broke it, and built over it a city in the east called Jäbura (Jablaqa; Maybe from hence the association of the broken mirror with misfortune, 7 years bad luck etc.). When Sulaymān b. Dāwüd - peace be upon them - became (ruler), he already knew of the mirror, and he inquired about it. He was told that Faqtash had taken it. So he summoned him and asked him about it. (Faqtash) said, 'It is beneath the foundations of Jāburq.' (Sulaymān) said, 'Bring it to me.' (Faqtash) said, 'But who will destroy these foundations?' Sulaymann was told to say to him, 'You yourself shall destroy them.' Sulaymān told him this, and Faqtash said, 'Very well.' He (then) departed, destroyed the foundations and brought the mirror to Sulaymān. Sulaymān restored it piece by piece and strengthened it on all sides with a leather band. Then he looked into it and saw whatever he wanted. When Sulayman died, the devils pounced on it and bore it away, and (only) one fragment was left, which was inherited by the Israelites, until it (finally) reached the exilarch of the Jews, who gave it as a gift to Marwān b. Muhammad b. Marwān (A.H.127132/744-750 A.D.) during his wars with the Abbasids. Marwān would then rub it, place it on top of another mirror, and see things that displeased him. When this had gone on for a while, he threw it away and beheaded the exilarch of the Jews. One of (Marwān's) slave girls then took it and kept it with her. When (the Abbasid) Abū Ja'far al-Mansür became caliph (A.H.136-158/754-757 A.D.), he already knew of it, and so he inquired about it. He was informed that it was in the possession of a slave girl of Marwān. He searched for it until he found it. Then it remained with him where he would look into it. It remained in the caliph's treasury for a long time; then it was lost" 20 .

This famous mirror, rediscovered and repaired by the Prophet Sulaymān b. Dāwūd, and of which only a single piece, a fragment of the whole mirror, reportedly reached the Abbāsid caliphs' treasury, could have been understood as providing the model for the subsequent use of

19 An apparent source-model for the historically subsequent mirror on the Pharos at Alexandria, mentioned by Benjamin of Tudela who in 1168 records in his Sefer ha-Masa'ot, (Tudela 2005, 104) the speculum on the Pharos was constructed by Alexander the Great; as likewise the mirror mentioned in the c. 1165 Letter of Prester John, as both of these mirrors enabled events in far distant lands to be observed, but both of these mirrors were however kept in towers. It seems from the Islamic sources that there probably was an East Roman mirror(s) which was destroyed on the Pharos in the late VII-VIII century A.D. which was possibly employed for signalling, rather than only relating to the intensification and projection of the flames' light into a beam, although this is uncertain. Johann Schiltberger relates the mirror on the Pharos at Alexandria was deliberately broken to enable the sack of the city by the Lusignan Crusaders in 1365, (Schiltberger $1879,62-4)$ when in fact the Pharos tower was no longer standing in 1365, and the mirror, if there was one, seems to have been lost some five to six centuries earlier.

20 al Qaddūmī 175. 
mirrors for the signalling-communication of the news, muhabereler news-intelligence in secure code to the ruler who saw his position as being that of the Second Sulaymān, and it may be that this account provides an indication of the date for the initial use of mirrors for Abbāsid signalling, post-dating the loss of the fragment of the original mirror from the Caliph's treasury, at some point in the period from the late VIII th to the middle of the $I X^{\text {th }}$ century A.D. as 'Umar b. Shabbah al-Numayī is recorded as living A.H. $172-262 / 789-875$ A.D. ${ }^{21}$ by which date the mirror fragment had been lost from the Abbāsid Caliph's treasury. After this mirror was lost the Abbāsid Caliph al-Ma'mun (813-33) offered the East Roman Emperor Theophilus 2,000 pounds of gold and peace between the Caliphate and East Rome, peace between Islam and Christendom, if Leo the Engineer would reside for a while in Baghdad ${ }^{22}$; clearly indicating the enormous value placed upon code-maker engineers, by both the Caliph and the Emperor. The Caliph's offer of gold and peace in exchange for the loan of Leo the Engineer was rejected by the Emperor. It seems possible that Leo the engineer (790-869) ${ }^{23}$, who had developed a coded visual signaling system linking Constantinople to the Eastern border ${ }^{24}$, was wanted by the Caliph for the development of a coded signaling system, perhaps an invitation to be associated with the development at this time of the Abbāsid "heliograph" system. If this account of Sulaymān's mirror marked the Abbāsid development of a form of plane mirror glass backed with a silvermercury amalgam, the technology possibly brought to Baghdad from China ${ }^{25}$, or, possibly a form of plane mirror glass backed by a tin-mercury amalgam, a technology that finally reached Venice from the east in the $16^{\text {th }}$ century, is unclear ${ }^{26}$, but it seems evident from this description of the 'original mirror' that it was of some form of glass, that shattered into fragments, not therefore a metal mirror.

The Second Sulaymān, the Rūm Seljuk Sultan consequently had in his dīwān officials who were fluent not only in Arabic and Persian, but also in: Greek, Armenian, Turkish, Georgian and Latin, and under the Pagan Mongol over-lordship, Mongolian ${ }^{27}$, as also in the writing of şifreciphers-codes and their decipherment ${ }^{28}$; as he also employed the skilled jinn-like muhandisnakkash, craftsmen-engineers ${ }^{29}$; craftsmen-engineers who unsurprisingly, frequently marked

21 al Qaddūmi 346, where there is a typo, A.D. 976 is given, rather than 875, as the date of death of 'Umar b. Shabbah al-Numayī.

22 Setton 1956, 30.

23 Symeon Magister describes the method devised by Leo the Engineer in the IX ${ }^{\text {th }}$ century employing two synchronous clocks to send 12 different messages defined by the hour they were sent. For the excavation of East Roman beacons, see: Foss 1985, 86-94; 1991 273-4. For more on Leo the engineer-philosopher see, Wilson 1996, 79-84.

24 Browning 1980, 73; For Leo the mathematician and engineer, see: ODB 235, 1217.

25 Although "Glass has been used to make mirrors since at least the $I^{\text {st }}$ century B.C., when mirrors were made of silvered glass in Egypt". Ward 2008, 249; contra, DeJean 2005, 178, "The earliest surviving bits of mirrored glass date from the third century A.D. and are so small (one to three inches in diameter) that they were probably used as ornaments rather than for grooming".

26 For the XIII ${ }^{\text {th }}$ century trade in glass mirrors, see, Krueger 1993, 319-332. For the transfer of glass cullet and raw materials to Venice from the Islamic World, see for example, Verita 2007, 276-9.

27 Köprülü 1992, 23.

28 Cahen 2001, 180.

29 Surat Saba' 34. 12 - 34. 13 "And among the jinn were those who worked for him by the permission of his Lord. And whoever deviated among them from Our command - We will make him taste of the punishment of the Blaze. They made for him what he willed of elevated chambers, statues, bowls like reservoirs, and stationary kettles". Surat Al-'Anbyā' 21. 82 "And of the devils [jinn] were those who dived for him and did work other than that. And We were of them a guardian"; Surat Şād 38. 37-38 "And [also] the devils [of jinn] 


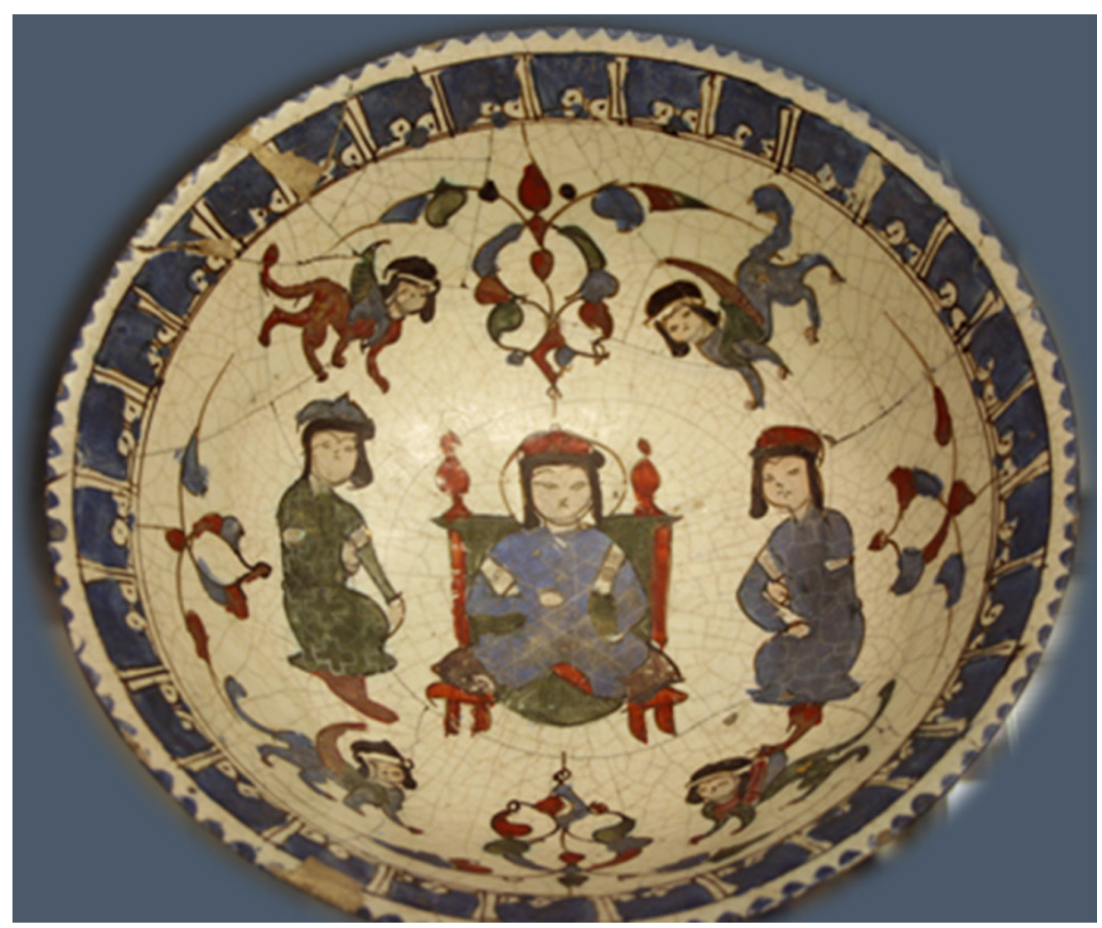

Fig. 1. Kashan, Iran, late XII ${ }^{\text {th }}-X I I I^{\text {th }}$ century mina'i-fritware bowI, B. M. London (Inv. 1930,0719.63). The scene in this bowl can be understood as depicting the enthroned Second Sulaymān with messengers to either side, crowned human headed winged lion figures-jinn; with the decoration between these figures representing the signalling mirrors, likewise centred on the enthroned Second Sulayman signalling at the speed of light. The inscription band below the rim represents a repeated coded message. The British Museum catalogue entry for this depiction reads: "Enthroned royal figure seated between two other figures, possibly attendents (sic) or visitors. Four sphinxes, two above and two below the seated figures. Stylised floral ornamentation between the sphinxes. Pseudo-Arabic inscription painted along the rim against blue background"

their works with the Seal of Sulaymān device, a 6 or an 8 pointed shamsa-Sun-Star, indicating not only that they were working for The Second Sulaymān, but also indicating the work's excellence with this mark, and a sign indicating those Muslim rulers who were perceived, wished themselves to be perceived as, and who saw themselves as, the embodiment of "The Sulaymān of the Age" - "The Second Sulaymān" ${ }^{30}$, ruling from the centre of a sophisticated communications network that went to wherever the ruler was (depicted in Figs. 1, 3, 4, 5).

The British Museum catalogue entry for Fig. 1, describes these depictions of jinn of the land as 'sphinxes', a 19 $9^{\text {th }}$ century orientalist misnomer as likewise in Fig. 2 below, the Christies 2012 sale catalogue describes the depictions of jinn of the air as 'harpies', (as likewise Watson 2004, Cat. P.6 'heraldic harpies') words derived from the cults of the Jahiliyyah-of antiquity, and, apart from the passing formal resemblance, have no meaning in an Islamic context, both words almost entirely unknown in the contemporary XII $-\mathrm{XII}^{\text {th }}$ century Arabic and Persian literature, although the Mushaf contains 146 direct and indirect references in Ayet to the jinn and, within

- every builder and diver and others bound together in shackles".

30 For remarks qualifying the positive view of the rightly guided temporal ruler, see for example Attar 42-3, where he relates of King Solomon and his ring-seal that due to the exercise of temporal power, even wearing the ring-seal of Sulaymān, blocking progress on the Spiritual Path, Sulaymān experienced a delay of 500 years before he could join the other Prophets in Paradise. 


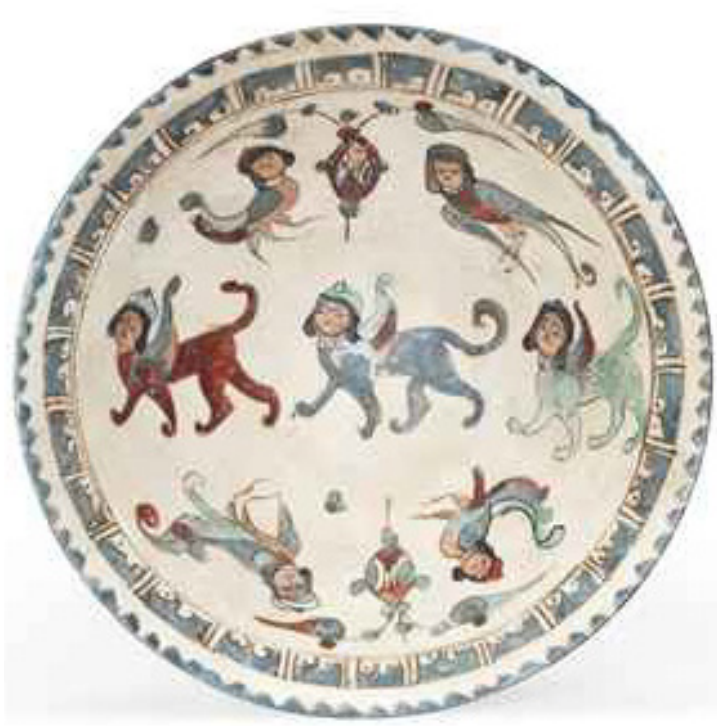

Fig. 2. Christies, London, Sale 6945 - Lot 7415, 5/10/2012. Kashan mina'i bowl c. 1200. The scene on this bowl can be understood as representing jinn-like rapid communications, represented by the depiction of three of the jinn of the land, and four of the jinn of the air either side of the pair of signal mirrors (above and below) and the whole surrounded by a band below the rim, repeated a coded message, as in Fig. 1 (above) and Fig. 3

(beside). The Christies 2012 sale catalogue describes the depictions of jinn of the air as "harpies' and it describes the stylised representations of the signalling mirrors as, 'palmette': "the central decoration with flanked by harpies at either side of a opposite palmette, the rim with a band of pseudo-calligraphic decoration on blue ground. $73 / 4$ in. $(19.5 \mathrm{~cm})$ diam"

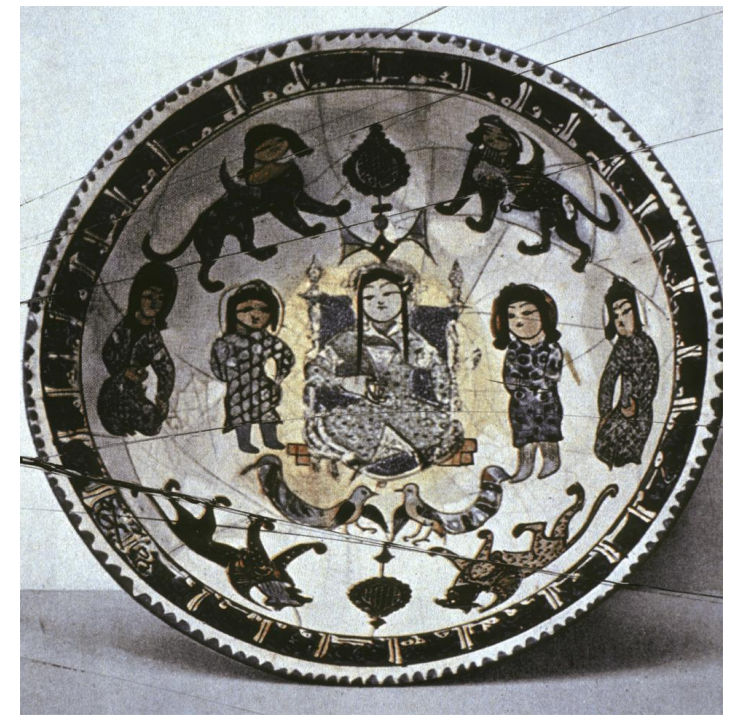

Fig. 3. British Museum, Kashan mina'i bowl c. 1200, depicting the enthroned ruler-The Second Sulaymān, messengers to left and right, paired messenger pigeons below the throne, above, paired Jinn of the Land separated by the representation of a signalling mirror, matching that opposite with paired griffons. The whole scene surrounded by a band below the rim, repeating what can be understood as a coded message, as in Figs. 1, 2

the Surat Al-Fātihah 1.2 is the expression 'Lord of the 'Alamin' (the 'Alamin consisting of: mankind, of jinns and of all that exists). Unlike the contextually meaningless 'sphinxes' and 'harpies' Jinn were carriers of significant meaning and were depicted, like the Seal of Sulaymān-Solomon.

This title of "The Second Sulaymān" was given to Sultan Mahmud of Ghazna 998-1030 (by Badi uz Zaman al-Hamadhani (d. 1009) ${ }^{31}$. And it was given to the subsequent Ghaznavid Sultans: Ma'sud III ${ }^{32}$ 1099-1115 and to Sultan Malik Arslan Ma'sud b. Ma'sud III (r. 1116) Mas'ud-i Sa'd-i Salman ${ }^{33}$; as also to the Great Seljuk Sultan Sanjar 1118-1157 by Khaqani ${ }^{34}$ (1106/7-1185), and to the Salghurid ruler of Fars, Abu Bakr Muzaffarud-Dīn, Qutlugh Khān b. Sad I b. Zangi (1226$1260)^{35}$.

\footnotetext{
31 Browne 1997, 113.

32 Bosworth 1977, 89.

33 Bosworth 1977, 91.

34 Browne 1997, 396.

35 Sâdi 6, 15; Blair-Bloom 1995, 23.
} 


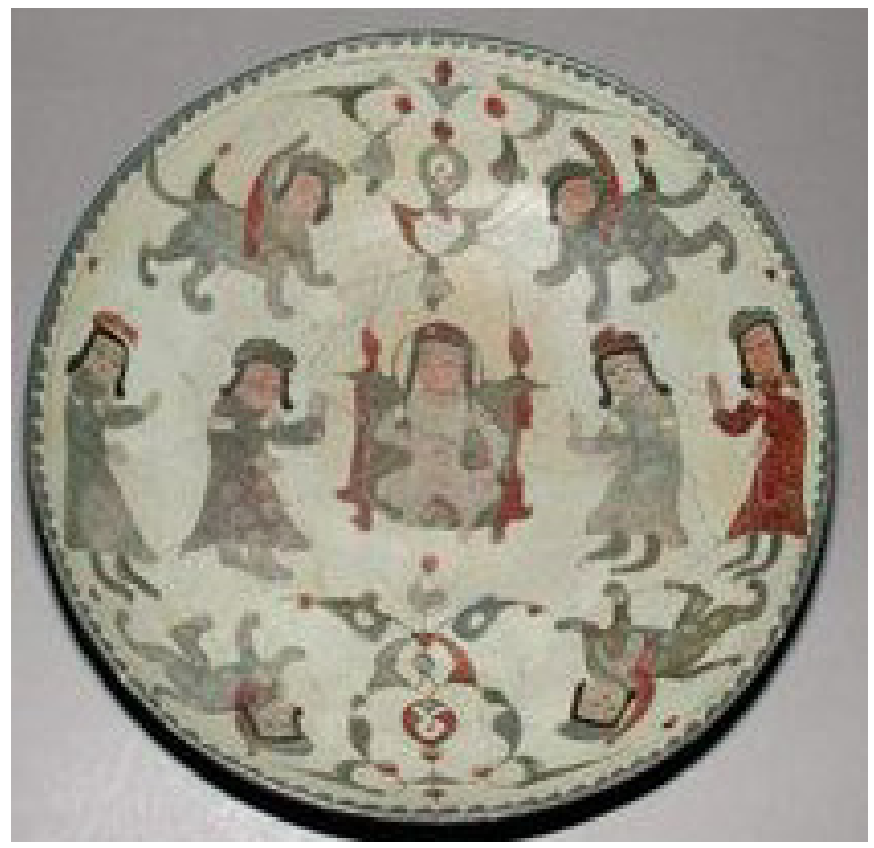

Fig. 4. Fitzwilliam Museum, Cambridge, mina'i dish, c. 1180-1219, (Obj. No.: C.135-1935). As with Fig. 1 above, the scene in this bowl can be understood as depicting the enthroned Second Sulaymann-the ruler, with human messengers to either side, while crowned human headed winged lion figures-jinn are paired either side of decoration representing the signalling mirrors, above and below the ruler, the signals reflected on these mirrors, likewise centred on the enthroned Second Sulaymān, signalling at the speed of light- that is, of the jinn. This scene represents The Second Sulayman-the ruler, being at the centre of the Seljuk communications, messaging system and thereby having the information at his disposal to act with wisdom. The Fitzwilliam catalogue entry reads: "This design comprises an enthroned figure, flanked by attendants to the right and left, as well as by griffins and arabesques above and below. The attendant figures have one arm raised toward the enthroned figure, all of them wearing gold leaf arm bands. Both humans and griffins wear red or grey hats and their robes, or coats, are painted in grey or red and are

lightly incised with a variety of patterns from circles to swirling tendrils. The pointed leaves of the arabesques are painted with grey and are adorned with red dots"

Ibn Bibi describes the arrival of the Seljuks in the lands of Rūm ${ }^{36}$ as being brought into this territory by the wind-breath of the Prophet Sulaymān ${ }^{37}$, a reference to both the Prophet Sulaymān (Al-Anbiya 21:81; Sad 38:36) and linked to the name and actions of the founder of the Rūm Seljuk Sultanate, Melik Sulaymān b. Qutlumush (1081-6). The name Sulaymān was also given to one of the sons of Sultan Kılıç Arslan II (r. 1156-92), Sultan Sulaymān-Shāh Rukn al-Dīn (r. 1197-1204), while ibn Bibi also described Sultan Kılıç Arslan II, as "The Second Sulaymān" ${ }^{38}$.

From the Sunni Muslim perspective, legitimacy for Rūm Seljuk rule in former East Roman territory over Muslims, and other populations, Christian Orthodox, Armenian and Jewish inhabitants - these non-Muslims forming the vast majority of the populations in XIIt ${ }^{\text {th }}$ century

36 Rūm as is recorded in the Surat Ar-Rūm (The Romans) - مورل مروس - hence, Malik ar-Rūm - Ruler of the Romans = the East Roman Emperor, eg. Usama 2008, 11 fn. 6, distinct from the Sultan ar-Rūm. While C. E. Wilson in 1924 relates of the word Rūm, "It is now applied by the Persians to the Ottoman Empire", Nizami II. 151, commentary on line, 546; I. 473.

37 Bibi I. 20; 79.

38 Bibil. 79. 
Rūm Seljuk territory, together with a small number of Latin-Frank Catholics ${ }^{39}$ - came from the recognition providing legitimacy for rule given to these Rūm Seljuk rulers by the reigning Abbāsid Caliph in Bagdad, through their investiture by the Caliph's envoy with the 'ahd, or investiture diploma, manshur, diploma of recognition awarding the title, Sultān, and the legitimizing symbols, the attributes and insignia of rule, including: the sea $\mathrm{l}^{40}$, the robes of honor, tashrif, sword with gold scabbard, horse with gold saddle ${ }^{41}$, chatr-parasol, standard crowned with a crescent moon which formed the finial, the alem of the standard sent by the Caliphs to Abbāsid recognized rulers upon their accession ${ }^{42}$. In exchange the Sultan was to mention the Abbāsid Caliph's name in the khutba, the Friday sermon given at congregational mosques throughout the realm, on the coinage ${ }^{43}$, and on the tiraz, the inscription bands on the garments worn by state officials as also by the Sultan ${ }^{44}$.

During the period from 1205 to 1246, that is, from the second reign of Sultan Giyath al-Din Keyhusrev I (r. 1205-11) ${ }^{45}$, through the reigns of: Sultan 'Izz al-Dīn Keykavas I (r. 1211-20) ${ }^{46}$, Sultan 'Ala' al-Dìn Keykubat I (r. 1220-37) ${ }^{47}$, Sultan Giyath al-Dīn Keyhusrev II (r. 1237-46), with his first wife from Georgia described as, like "Belkis" the wife of the Prophet SulaymānSolomon ${ }^{48}$, in the surviving literary record, each of these Rūm Seljuk Sultans were described by the laqub "The Second Sulaymān".

Clearly, following the execution by the Pagan Mongols of the last Abbāsid Caliph, al-'Imām al-Musta'sim in 1258 in Bagdad, there was the matter of the absence of legitimacy, there being no longer the possibility of the dispatch of title and insignia from the Caliph to the Rūm Seljuk ruler, thereby legitimising the ruler as being the representative of the Abbāsid Caliph, nor the expression of this recognition in the khutba, nor on the tiraz or the coinage of the Sultanate naming the Caliph; this was combined with the increasing Pagan Mongol control over Rūm Seljuk territory, consequently the title, "The Second Sulaymān" seems not to have been given to subsequent Rūm Seljuk rulers, and the title of sultān adopted by post 1258 Rūm Seljuk rulers, was "de facto" and, in legal terms, usurped, in the absence of the legitimate investiture by the Caliph or his representative, upon the accession of each sultan. The circumstances of the post 1258 period were quite unprecedented, and these circumstances were not aided by the very young age of the co-holders of the title 'sultān' in Rūm Seljuk territory in the post 1259 period, following the death of the last legitimate Rūm Seljuk Sultan Kılıç Arslan IV.

Consequently with the Rūm Seljuk Sultans from 1205 to 1243/6 described through the laqub as "the Second Sulaymān", one may think these sultans so described, may, reflecting a recorded attribute of the Prophet Sulaymān, have possessed an effective communications system, employing

39 As recorded in an inscription of 1231, "the sultan of the land and sea, of Greeks (sic. Rüm=Romans-East Romans), Syria, the Armenians and the Franks", Lloyd - Storm Rice 1958, cat. no. 36.

40 Bibi I. 241.

41 Serjeant 1972, 24.

42 Bosworth 1977, 99. For the hilal-i rayat sent to the Ghaznavid Bahram Shah together with a black banner with a lion device and the black chatr or parasol. In respect to the black, the official colour of the Abbāsids, see Mas'udi 408; “Abbāsian means black,' Nizami II. comm. line I. 182.

43 Bosworth 1977, 79.

44 For examples: Serjeant 1972, 24, also 18, 19, 23; Bosworth 1973, 52-4; Khaldun 219-221.

45 Bibi $89-90$.

46 Bibi 181.

47 Bibi 1996, 232, 238, n. 596.

48 Bibi 1996 II. 37. 


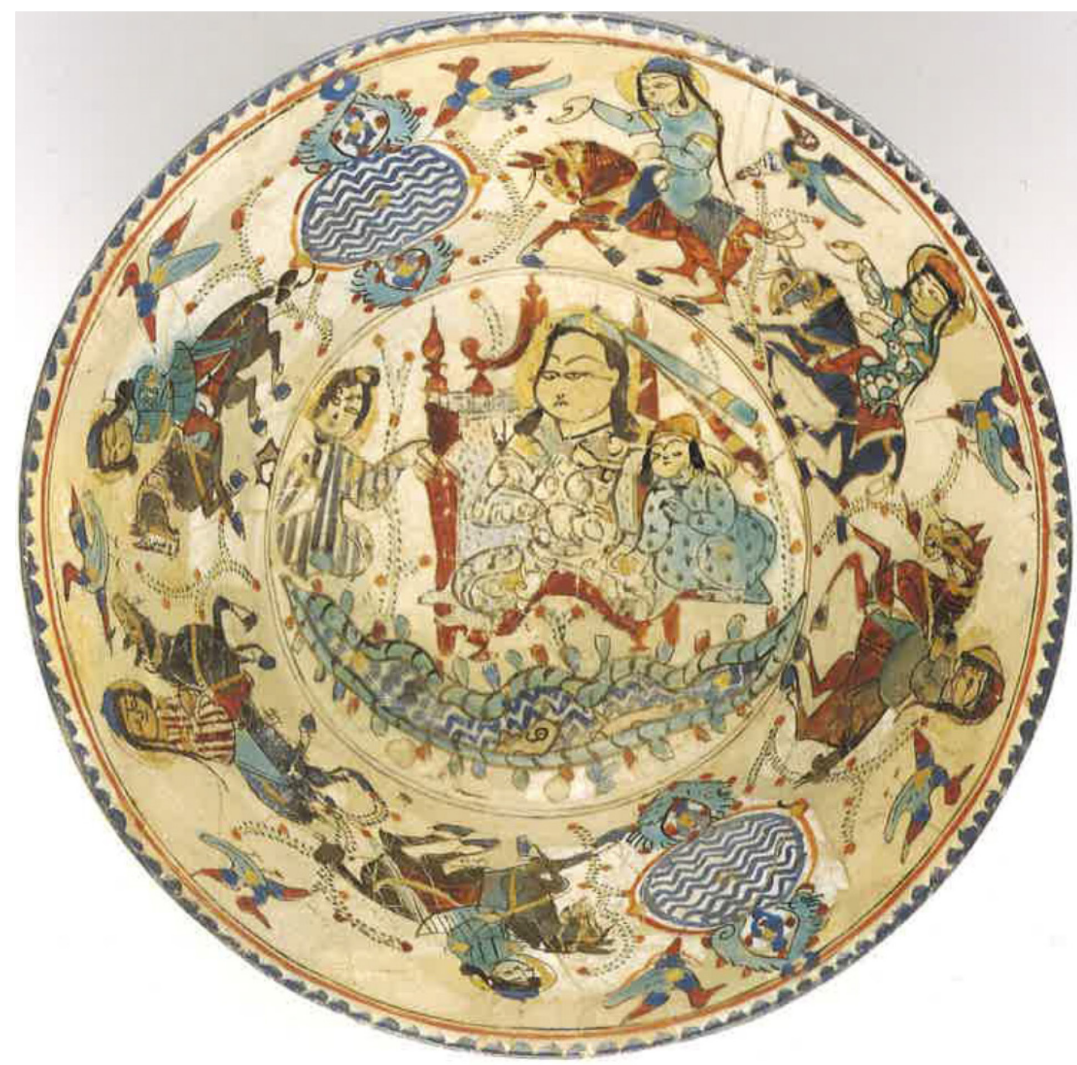

Fig. 5. Mina'i-ware bowl, Iran c. 1200. Museum für Islamische Kunst, Berlin, (Forkl 1993 abb.72). The enthroned ruler sits in the centre and it seems possible the figure to the left is bringing the news-reportsintelligence. While the inner border of the bowl carries depictions of the couriers and the messenger pigeons. The circular objects with a blue and white zig-zag pattern on the face, which are facing each other across the enthroned ruler, the centre of the state, each with two pairs of wings, can be understood as representing signalling mirrors flashing messages. It is noteworthy that the same design appears on the kiswah of the kaaba, as on the flags borne by Muslim forces depicted in contemporary miniatures, in tile-work, carved on stone columns, painted on the exterior walls of Rüm Seljuk state structures and elsewhere (as subsequently recorded on the flags of the coastal emirates in XIV ${ }^{\text {th }}$ century in Anatolia, in the case of the Teke Beylik of Antalya, together with the six pointed Seal of Sulayman device, presumably the design on the flag of the XIII ${ }^{\text {th }}$ century Rüm Seljuk Sultan's Emirs), and it seem this pattern can be

associated with, The Light, with the flash of the Sun-that is, with illumination from the Almighty

rapid communications, not just the barid courier-intelligencer service, but communications at all three degrees of speed, the messengers of the barid, the relays of messenger pigeons, and the messages that travelled at the speed of sight and light.

In respect to the barid, there is of course no reason to assume that the barid system was not employed in Rūm Seljuk territory, just because the Great Seljuks refused to employ it, to Nizam al-Mulk's recorded frustration:

"From ancient times onwards kings have preserved this system, except for the house of Saljuk who have shown no interest in the matter"49.

The absence of the barid and its intelligence officials $n \bar{a}^{\prime} i b-i$ barid employed by the Ghaznavids in the $\mathrm{XI}^{\text {th }}$ century, within Great Seljuk territory was said to have facilitated the

49 Darke 1978, 71. See also, Silverstein 2007, 136-7. 
activities of the Fatimids and Isma'îliss. In Rūm Seljuk territory a barìd type system based upon the XIII ${ }^{\text {th }}$ century non-urban state hān network (the word caravanserai tends to mislead as to the function of these buildings, placing a subsequent Ottoman-Safavid model for their function upon a XIII ${ }^{\text {th }}$ century Seljuk building, which was termed in the XIII ${ }^{\text {th }}$ century a hān, not a caravanserai) would have expedited communications with its exchange of post horses, kept in the courtyard, for the Sultan's kāsıd-messenger and ulak-intelligencer/envoy, a vital task, as was reportedly the case earlier for hāns in Ayyūbid territory ${ }^{50}$, as Carole Hillenbrand relates:

"and their function as stations for official couriers (in the barid service), weighed at least as much with their patrons - themselves servants of the state - as did their narrowly mercantile raison d'être ${ }^{\prime \prime 51}$.

This tripartite system of communications was employed by the Ayyūbids in the territory adjacent to Rūm Seljuk territory ${ }^{52}$ and, given the close connections between the Ayyūbid and Rūm Seljuk Sultanates in the first half of the XIIIt century, it seems most probable that a similar tripartite communication system to that employed by the Ayyūbids would have been employed in the first half of the XIII ${ }^{\text {th }}$ century by Rüm Seljuk rulers. These connections included: not only the Damascus based Andalusian, the Murcia born Muhyal-Dīn Ibn 'Arabi (1165-1240), who was familiar with Ayyūbid nūr based designs which had developed under the patronage of Sultan Nūr ad-Dīn Abū al-Qāsim Maḥmūd ibn 'Imād ad-Dīn Zengī (r. 1146-1174) and further developed and employed under the Ayyūbids - designs he may have helped to spread in his extended visits to the Seljuk palace cities of Konya in 1204-5, Sivas in 1216 and Malatya in 1216-1218 and in 1221, as it is recorded he taught at least one painter in Konya, not the method, but the aim in making by means of art, the aim being the expression of a metaphysic ${ }^{53}$; the use of Ayyūbid style calligraphy for a distinct group of Rūm Seljuk naskhi building inscriptions ${ }^{54}$; and there were also Ayyūbid trained architects in Rūm Seljuk territory, working at Sinope, at Konya, at Alanya, who designed Sultan-hāns, such as that on the Aksaray-Konya road at Sultanhānı. These Ayyūbid trained architects included: Abū 'Alī Abu 'r-Raqqā' al-Kattānī al-Halabī (of Aleppo), known to have been active in Rūm Seljuk territory from dated inscriptions in the period from 1216 to 1228, and the Damascene, Muhammad bin Hawlan al-Dimashqi, active in Rūm Seljuk territory from before 1219 to 1229. And there was the consolidation of this Ayyūbid-Rūm Seljuk relationship in the dynastic intermarriage of $1237^{55}$; together, at times, with a shared interest in the Jihad.

This tripartite system consisted of firstly the barid, the courier service, kussâd-messengers on horseback, employing as appropriate the extensive network of non-urban state hān-derbent stations for re-mounts. Secondly, the hamān, the messengers of the pigeon post ${ }^{56}$. Thirdly, line of sight observation, marker and signalling stations - manār-manāwir employing light, reflected light, and smoke ${ }^{57}$. This communication system is recorded pictorially on the Iranian c. 1200 fritware vessels painted in the mina'i technique (Figs. 1, 3, 4), human bearers of messengers, mirrors

50 For $\mathrm{XII}^{\text {th }}$ and $\mathrm{XIII}{ }^{\text {th }}$ century Ayyūbid non-urban state hāns, see for examples, photographs and plans, Sauvaget 1994, 308-319.

51 Hillenbrand 1999, 351.

52 Duggan 2014; forth. b.

53 Arabi $40-41$.

54 As was noted by Max van Berchem who described it as, Ayyūbid naskhī.

55 Eg. Younis 2014.

56 Addressed in detail in: Ragheb 2002, see also Silverstein 2007.

57 For further on this tripartite system see Duggan 2014; forth. b. 
and depictions of the jinn; and of mounted couriers, messenger pigeons and winged signalling mirrors (Fig. 5).

It was through employing rapid communications, not just the barid, but messenger pigeons, and 'flash' messages passed at the speed of sight and light and reflected light (like the smoke-less fire of which the jinn are made, Surat Ar-Rahmmān 55:15 of scorching fire, Surat Al-Hijr 15:27), that these Rūm Seljuk Sultans, informed through these means, could rightly be characterised as being "the Second Sulaymān".

That both Sultans 'Alā' al-Dīn Keykubat I and Gīyāth al-Dīn Keyhusrev II saw themselves, and wished themselves to be seen as, being identified as "The Second Sulaymān", is clearly recorded, not only by ibn Bibi, as noted above, but this is also recorded through some of the figures depicted on the 8pointed star-sun tiles employed on the cut-tile revetments on the walls of their palaces, pavilions

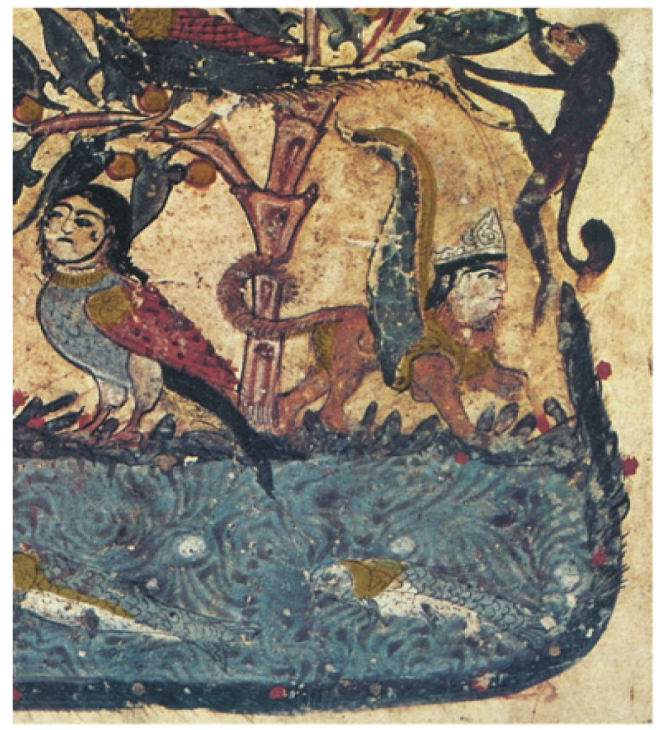

Fig. 6. Detail from $f .121$ of the "Schefer Hariri" of 1236, painted in Baghdad by alWasiti, Bib. Nat. Paris, MS Arabe 5847 (from Müller 1979) illustrating the Isle of Wak-Wak, depicting examples of both the Jinn of the Air and the Jinn of the Land and baths, as also on the Güdük Minare in Akşehir of 1227 where the square tiles carry these same 8-pointed star-sun designs ${ }^{58}$. Many of these tiles depict individual members of the 4 armies of the Prophet Sulaymān of: men, animals, birds and $\mathrm{jinn}^{59}$, with these armies analogous to those of the Second Sulaymān's: human messengerswatchmen, the couriers' mounts, the messenger pigeons and the flashing lights-smoke of signals, the jinn ${ }^{60}$. For examples of the depiction of these Jinn figures, see below Figs. $1-4,6-10$. Presumably the paired dragon figures that are depicted on these Seljuk palace tiles are to be understood as representing the jinn, although the creature that is called a 'griffon' depicted on these tiles (Fig. 3) $)^{61}$, as elsewhere freestanding in bronze ${ }^{62}$, is a creature that is described by Ibn 'Arabi as being, potentially in existence, but not existing, and is a secret known only to the Prophet Sulaymān ${ }^{63}$, thereby associating this depiction on tile-work, as its depiction in other materials, like these representations of the jinn, with the Prophet Solomon- Sulaymān and so, with "The Second Sulaymān". These remarks would also seem to apply to the tile-work painted in mina'i technique, probably originally from the Kılıç Arslan II pavilion in Konya (eg. Fig. 8), but given the few surviving examples this is uncertain, although Ibn Bibi likewise describes Sultan Kılıç Arslan II as "The Second Sulaymān", as is noted above.

58 Arık - Arık 2008, figs. 256, 257.

59 Surat An-Naml 27. 17: "And gathered for Solomon were his soldiers of the jinn and men and birds, and they were [marching] in rows"; Surat Al-'A'rāf 7. 27; Duggan 2006, 206-7; 2009, 235ff; Mardrus - Mathers 1996, vol. II. 293. For the two kinds of jinn, Surat Al-Jinn 72. 11.

60 For the work of the jinn: Surat Saba' 34. 12; Surat Şād 38. 37; Duggan 2009, $235 f f$.

61 Examples include those produced under the Fatimids in the $\mathrm{X}^{\text {th }}-\mathrm{XI}^{\text {th }}$ century, e.g. in lustre, Ettinghausen Graber 1994, fig. 157.

62 Ettinghausen - Graber 1994, fig. 188.

63 Elmore 1999, 80 n. 68. 

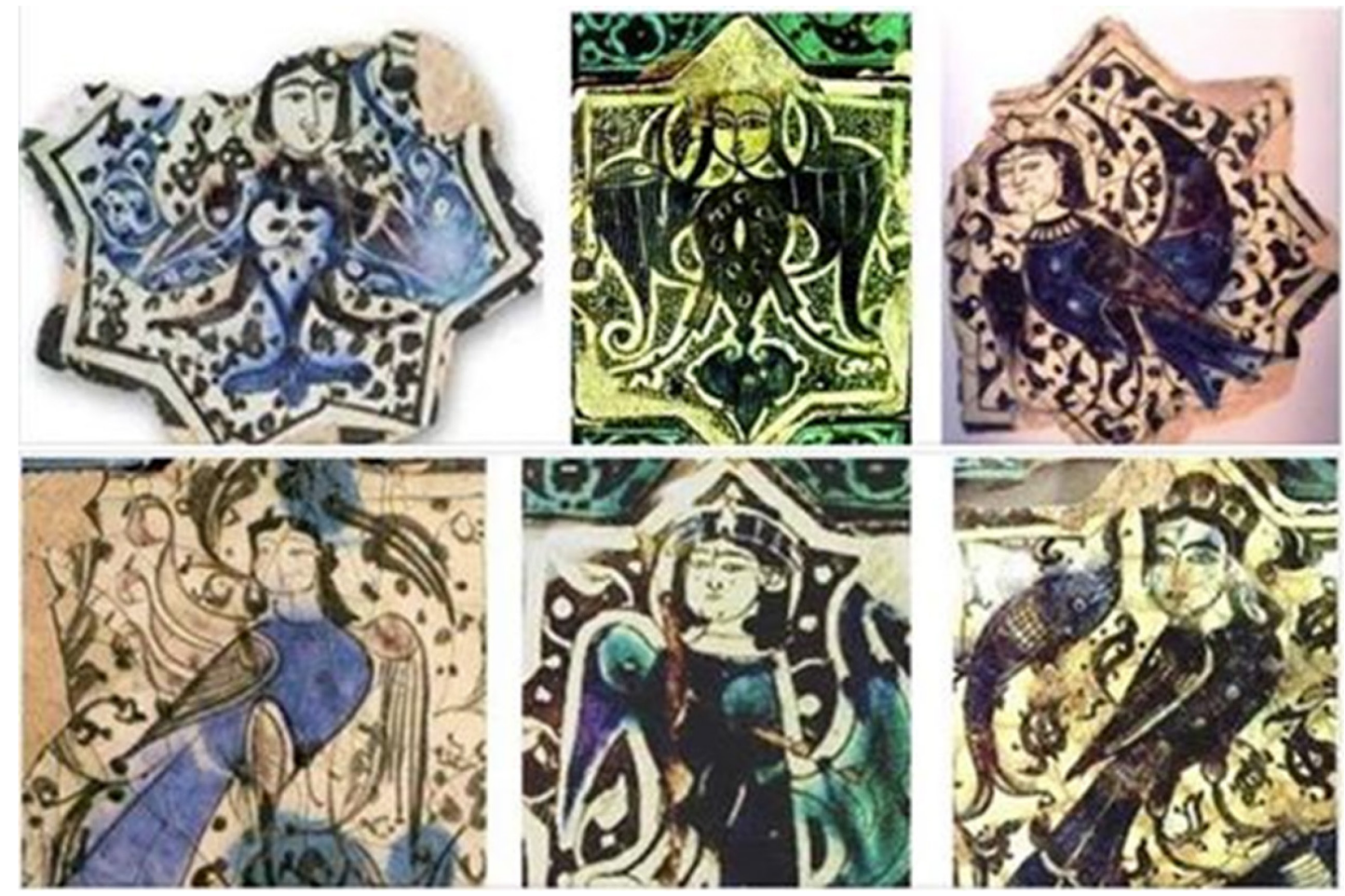

Fig. 7. Examples of the Jinn of the Air, crowned human-headed birds depicted on Seljuk XIII ${ }^{\text {th }}$ century tilework from Kubad Abad. From Arık 2000. Usually entirely misleadingly termed "sirens"

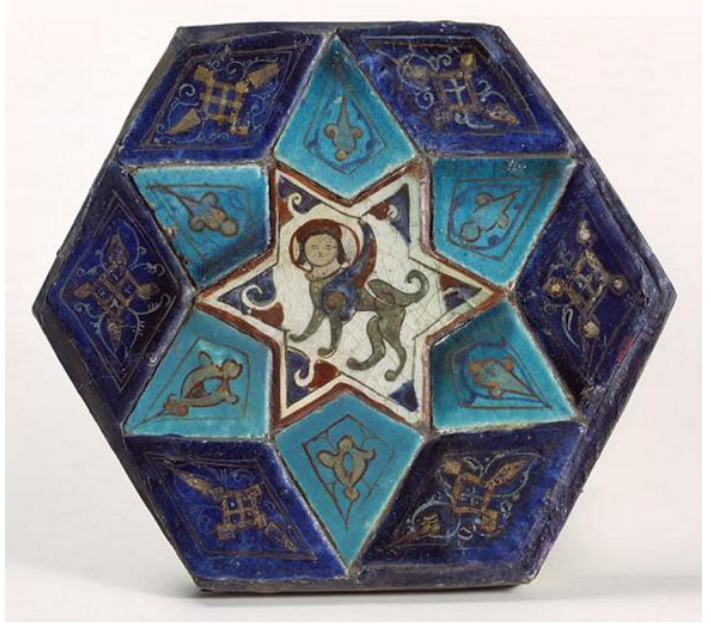

Fig. 8. Depiction of a Jinn of the Land, a crowned human headed winged lion, painted in mina'i technique, probably from the Kılıç Arslan II pavilion, Konya, today in the Metropolitan Museum, New York, from Arık - Arık 2008

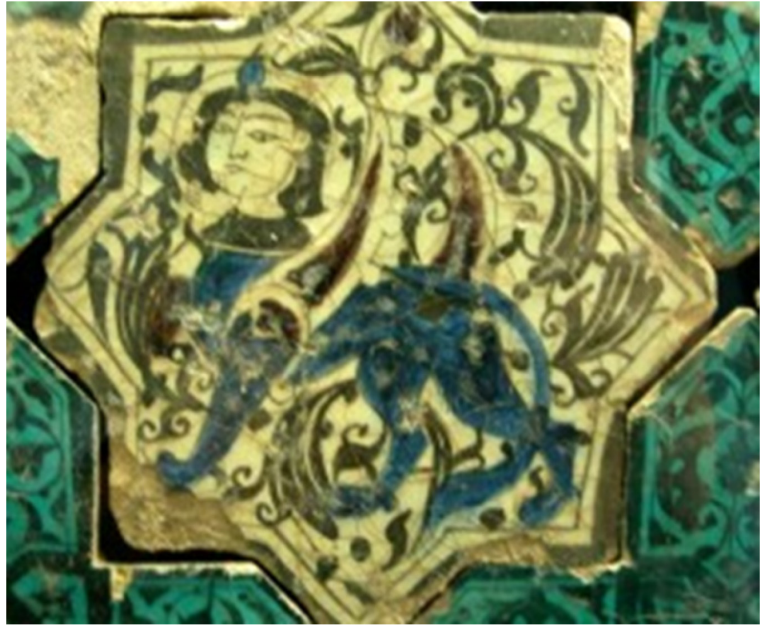

Fig. 9. Example of a Jinn of the Land, crowned human headed winged lion, depicted on Seljuk XIII th century tile-work from Kubad Abad Palace, Beyşehir, from Arık 2000. It is therefore unsurprising that Seljuk bronze mirrors frequently have on the reverse the depiction of a pair of crowned, human headed, winged, lions, (fig. 10) these figures representing the Jinn of the Land travelling at the speed of light, in the blink of an eye, Surat An-Naml 27:38-9, in the flash of a reflected message 


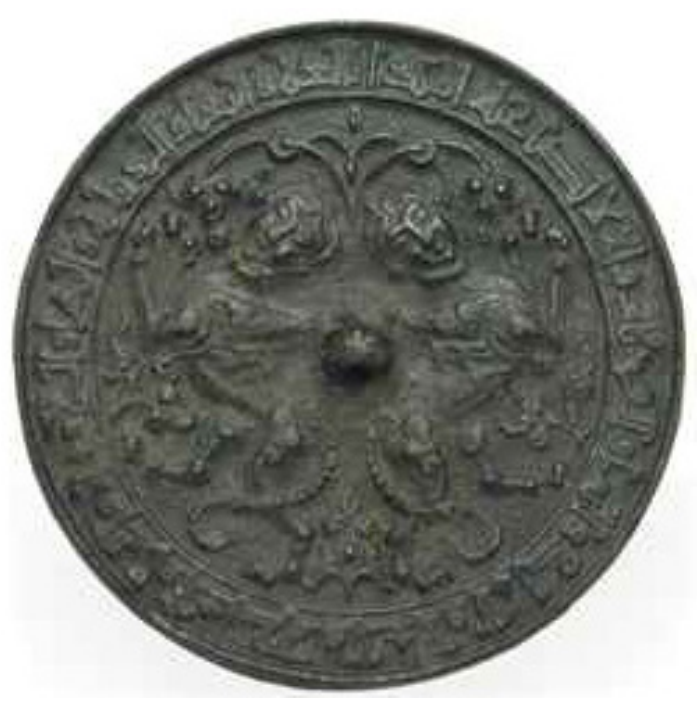

Fig. 10. Reverse of a characteristic Great Seljuk bronze mirror carrying relief depiction of paired Jinn of the Land (In the Christies Sale Catalogue Sale 4914 -Lot. 709, 27-04-2012), the Jinn of the Land are, as is regrettably typical, misleadingly described as "sphynxes": "Cast with two addorsed sphynxes among sprays of foliage within a benedictory inscription band in kufic script reading: al-'izz wa al-baqa' wa al-dawla wa al-baha (?) wa al-rafiya (?) ... wa al-ghibta wa al'ala wa al-mulk ... li-sahibihi, the centre with a raised attachment ring , 4.1./8in. (10.6 cm) diam"

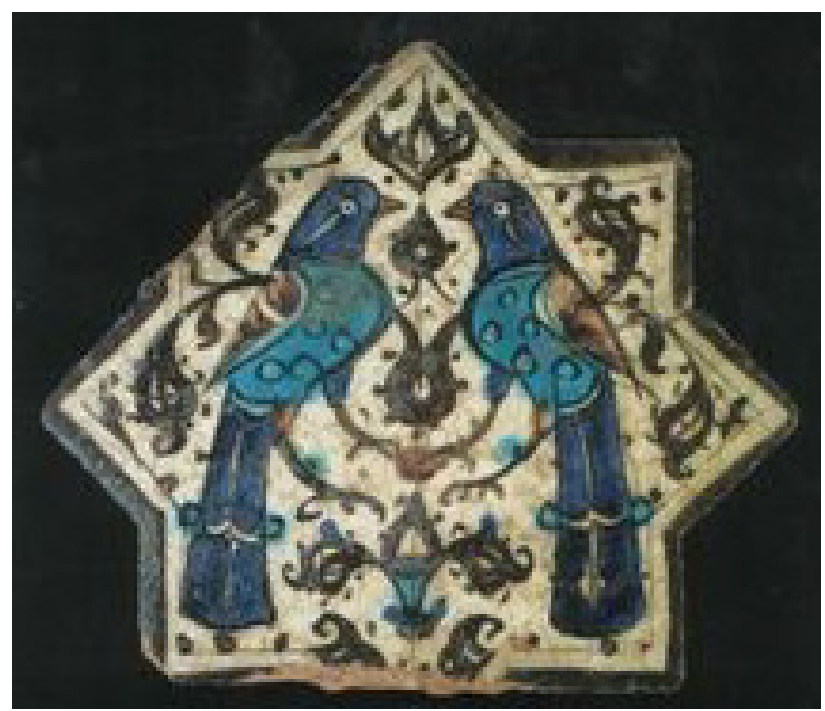

Fig. 11. Depiction of a pair of birds, most probably messenger pigeons, if the design on the tail feathers represents the attachment for a message is uncertain, but seems not improbable. As to if this pair together represent the message sent and the reply received, via the hamann, an image of the pigeon post repeatedly depicted on 8 pointed sun-star tiles from Kubad Abad and other Rüm Seljuk palaces and pavilions' tiled revetments, it seems possible 


\section{The Manār by Şarâb-sa Hān}

The manār (fig. 12) immediately to the west of Şarâb-sa hān ${ }^{64}$, was a rectangular tower that stood to the height of the adjacent hān in the 1920's, located $8 \mathrm{~m}$ to the west of the west end of Şarâb-sa hān ${ }^{65}$.
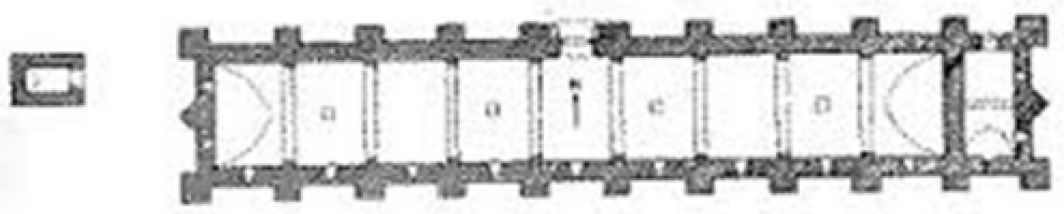

Fig. 12. Plan (from Erdmann 1961) of the manār and adjacent the Şarâb-sa hān

Only the base and ground floor of this manār remains in situ today (Fig. 13, Fig. 14). It was probably constructed prior to the construction of the adjacent hān, which was built during the reign of Sultan Giyāth al-Dīn Keyhusrev ${ }{ }^{66}$. The manār, from the style of masonry and mortar employed and from the apparent form of the merlons ${ }^{67}$, and with its exterior measurements of 5 by $6.5 \mathrm{~m}$ on its longer sides facing North and South, measuring one half of the width of the hān if measured from outer wall to outer wall, ignoring the exterior buttresses, suggests the employment of the same system of measurement and methods of construction for both buildings, with the manār originally standing at least as high as the hān. The above suggested subsequent construction of the hān in this place was doubtless likewise related to the Sultan's communication systems, this hān adding a station to the overland barid system at time when secure accurate muhabereler news-intelligence was invaluable (Fig. 15), with the public posture

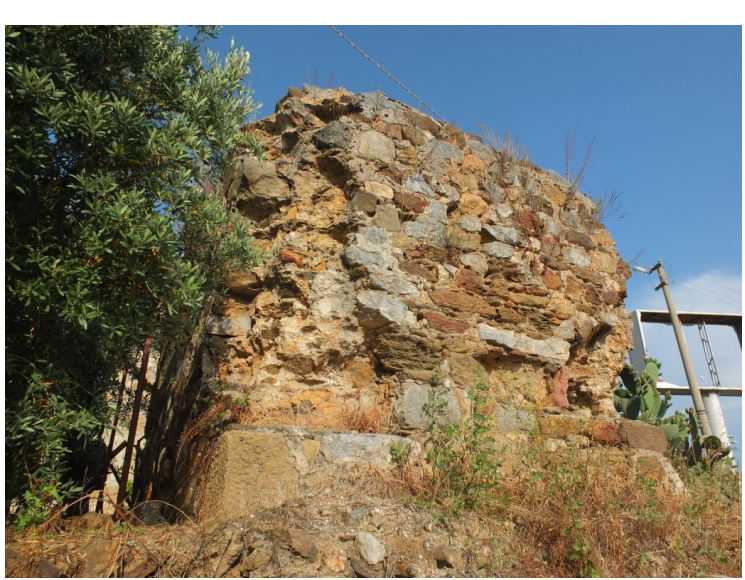

Fig. 13. Side of the manār by Şarâb-sa hān from the south of the Rūm Seljuk Sultanate as a great power, rich, dynamic, dynastically well connected, with a powerful mercenary army elite, contrasting so markedly with the threats presented to it by the Pagan Mongols, the rebellious Turkmen and the Shī'a Imāmī Nizāri Ismā'îli assassins looking for their annual protection money payments ${ }^{68}$.

It seems possible, given its suggested function, that this manār tower was first constructed during the reign of Sultan 'Alā' adDin Keykubat I after the 1221 conquest of Kolonoros (Alanya), forming a part of the communications system linking the new pos-

64 Yılmaz - Tuzcu 2010, 27-30, fn. 35; for the title Şarâb-salâr see Kaymaz 2011, 122.

65 Erdmann 1961, I. cat. no. 53, 173; II, abb. 319, from a photograph in the R. M. Riefstahl archive taken in 1929; in the 1950's, idem, abb. 320; Lloyd - Storm Rice 1958, pl. XI (d) where the single storey remaining at that date is clearly visible beside the hān, but which is unremarked upon in the text and not included in the plan; likewise not recorded or remarked upon in Vakıf 1983, 607-10.

66 Inscription on the hall portal names this sultan, Lloyd - Storm Rice 1958, no. 34; Erdmann 1961, I, 173; Vakıf 1983, 610.

67 Erdmann 1961, II. abb. 319.

68 Daftary 2007, 390, citing, Abu'l Fada'il Muhammad b. Ali, Al-Hamawi, al-Ta'rikh al-Mansuri. Ed. P. A. Gryaznevich, Moscow (1963) 335-6. 
sessions and territory with both Antalya and Konya.

It was probably in part rebuilt after, almost inevitably, being damaged in the major earthquake and tsunami of the $11^{\text {th }}$ of May 1222, which totally destroyed the western Cypriot coastal city of old Paphos, recorded in the Byzantine Short Chronicles $^{69}$, destroying its harbour, and also its castle which had been built only 30 years earlier and it damaged parts of Limassol and Nicosia, and this earthquake was associated with a major tsunami ${ }^{70}$. There can be little doubt that this earthquake and tsunami must have caused significant damage along this coastline, in addition to the de-

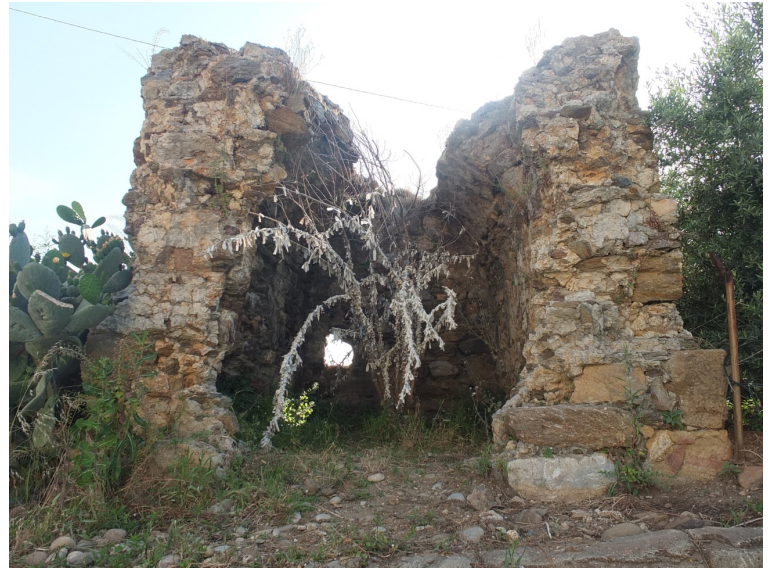

Fig. 14. Side of the manār by Şarâb-sa hān from the east struction caused at newly taken, restored and renamed 'Alā'iyya-Aliyya-Alanya, and the destruction this seismic event caused seems a reasonable explanation for the strange absence of Seljuk inscriptions dated to the years 1221-1222 from the 'Alā'iyya fortifications, yet we know the fortification walls would have been repaired immediately following the considerable damage they experienced from the mangonel projectiles fired during the course of the Seljuk siege, these shattered Seljuk building inscriptions from 1221-1222 presumably being reused in the subsequent Seljuk rebuilding work.

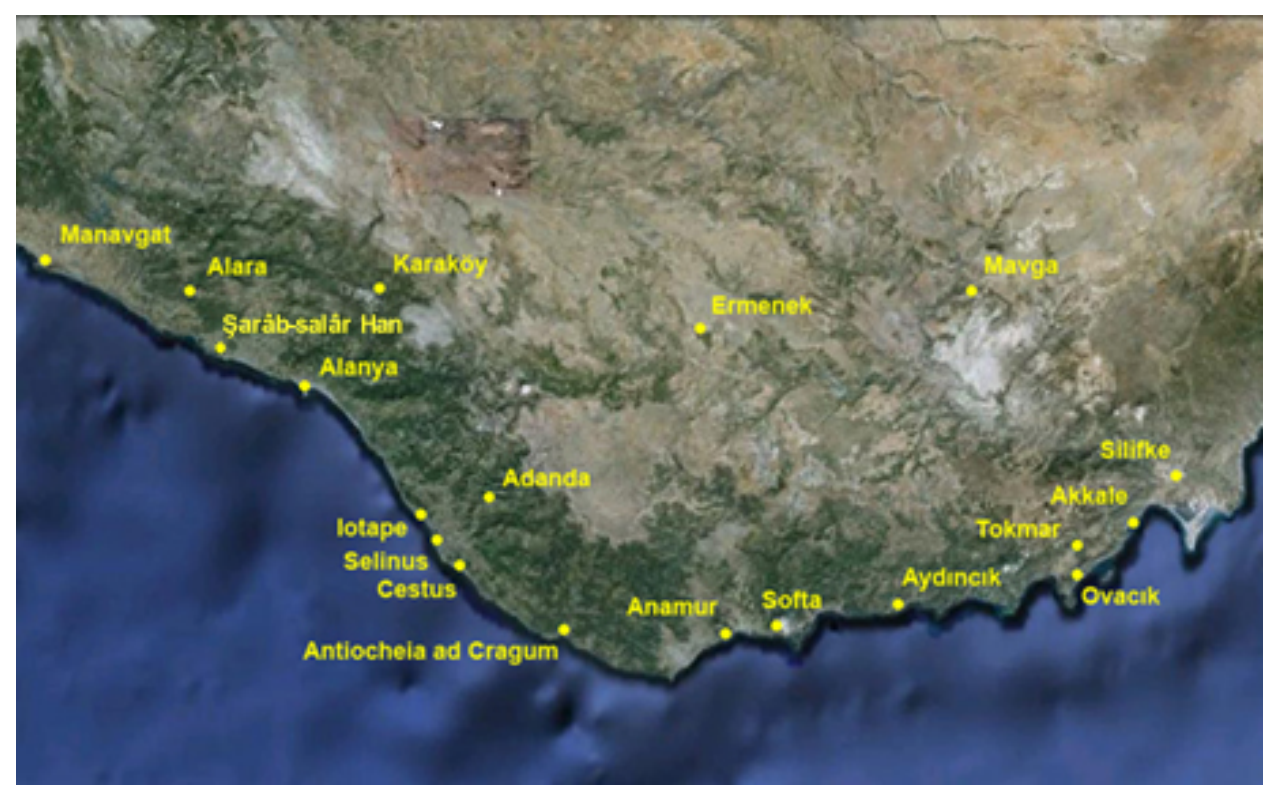

Fig. 15. Map from Google.earth.com, Şarâb-sa hān being on the coast between 'Alä'iyya-Alanya and'Ala'ra-Alara, indicting both the rugged terrain and the coastal castles-harbours and settlements taken in the Seljuk naval part of the 1225 Jihad campaign, when communications extended along the coast from

Dalaman to by Silifke

69 Schreiner 1977, II. 191.

70 Al-Magrizi 146; Arık 1994, 22; Edbury 1994, 14; Altan 2002, 46. 
This rectangular two storied manār tower constructed on a minor elevation of $8 \mathrm{~m} \mathrm{ASL,} 500$ $\mathrm{m}$ from the sea and with a then entirely unimpeded sea vista, seems to have been constructed to serve as a Seljuk coastal watch and signalling relay tower, its signals would have been clearly visible from $15 \mathrm{~km}$ away, night and day, weather permitting, from the citadel of Ala'iyya-Alanya and vice versa. This Rūm Seljuk manār, like the Yivli mubārak manār of Seljuk Antalya, the Taşdibi manār by the Medieval port of $\mathrm{Myra}^{71}$, the Yilan başlik manār on Cape Gelidonya (destroyed by seismic activity in 1741) and the Seljuk re-use of the Roman Pharos at Patara as a manār, were not constructed or restored and reused to function solely as harbour markers, there is no harbour by Şarâb-sa hān, nor on Cape Gelidonya, but rather these formed part of an integrated Rūm Seljuk XIII ${ }^{\text {th }}$ century coastal surveillance, marker and communications system. Constructed to provide for secure and rapid communications - at the blink of the eye - this being an attribute of the Prophet Sulaymān, and, to a lesser degree, an attribute of those Caliph's and Sultans who were described as being the embodiment of "The Sulaymann of the Age", who were in their time understood as being, "The Second Sulaymān", with the jinn at their command ${ }^{72}$, the muhandis-nakkash producing works of superlative quality, designing and refining communication systems, codes and instruments ${ }^{73}$, enabling the passing of coded messages flashed at the speed of light-reflected light, from manār to manār.

\section{Figure Sources}

Fig. 1. http://www.britishmuseum.org/research/collection_online/collection_object_ details/ collection_image_gallery.aspx?assetld $=229466001 \&$ objectld $=217543 \&$ partld $=1$

Fig. 2. http://www.christies.com/lotfinder/lot/a-minai-pottery-bowl-kashan-central-iran-56046 72-details.aspx.

Fig. 3. https://www.studyblue.com/notes/note/n/islamic-art-slide-quiz-3/deck/8465339.

Fig. 4. http://webapps.fitzmuseum.cam.ac.uk/explorer/index.php?oid=71856.

Fig. 5. Forkl-Kalter - Leisten-Pavaloi 1993, Abb. 72.

Fig. 6. Müller 1979.

Fig. 7. Arık 2000.

Fig. 8. Arı - Arık 2008.

Fig. 9. Arık 2000.

Fig. 10. http://www.christies.com/lotfinder/lot/a-seljuk-cast-bronze-circular-mirror-iran-55529 o0-details.aspx

Fig. 11. Arık 2000.

Fig. 12. Erdmann 1961.

Fig. 13. Photo Mahmut Demir.

Fig. 14. Photo Mahmut Demir.

Fig. 15. Google.earth.com.

71 Duggan - Aygün 2015.

72 It seems possible that the relief that gave its name to the Talisman Gate of Bagdad of 1221, depicted the Abbāsid Caliph Abū Nasr al-Zāhir (1226-42) as the Second Sulaymān, holding the tongues of the Unbelieving Jinn, represented as winged dragon-like creatures. With, it can be proposed, a similar meaning to the carvings of this subject either side of the portal of Sinjar's al-Khān.

73 Duggan forth. b. 


\section{BIBLIOGRAPHY}

\section{Medieval Sources}

Al-Magrizi

Arabi

Attar

Bibi

Khaldun

Mas'udi

Nizami

al Qaddūmī

Sâdi

\section{Modern Literature}

Altan 2002

Arık 1994

Arık - Arık 2008

Arık 2000

Blair - Bloom 1995

Bosworth 1977

Bosworth 1973

Browne 1997

Browning 1980

Cahen 2001

Daftary 2007

Darke 1978

DeJean 2005
Al-Magrizi, A History of the Ayyubid Sultans of Egypt. Trans. R. J. C. Broadhurst. Boston 1980

Arabi, The Sufis of Andalusia-The Rūh al-quds and al-Durrat al-fäkhirah. Trans. \& Ed. R. W. J. Austin. London 1970.

Farid ud-Din Attar, The Conference of the Birds. Trans. \& Intro. A. Darbandi-D. Davis. London 1984.

Ibn Bibi El-Hüseyin b. Muhammed b. Ali El-Ca'feri Er-Rugadi, El Evamirü'lAla'iye Fi'l-Umuri'l-Ala'iye, (Selçukname), vols. I-II. Trans. M. Öztürk. Ankara 1996.

Ibn Khaldūn, The Muqaddimah - An Introduction to History. Trans. F. Rosenthal. Princeton - Oxford 2005.

Mas'udi, The Meadows of Gold, The Abbasids. Trans. \& Ed. P. Lunde - C. Stone. London - New York 1989.

Nizami, The Haft Paikat by Nizāmī of Ganja, vols. II. Trans. \& Comment. C. E. Wilson. London 1924.

The Book of Gifts and Rarities - Kitāb al-Hadāyā wa al-Tuhaf. Trans. \& Ed. G. H. al Qaddūmī. Cambridge - Massachusetts 1996.

Sâdi, The Rose Garden of Shekh Muslihu'd-Din Sadi of Shiraz. Trans. E. B. Eastwick. London 1974.

E. Altan, "1150-1250 Yılları Arasında Anadolu'da Doğal Afetler". Ed. Anonymous, Istanbul Üniversitesi Tarih Araştırmaları Merkezi Tarih Boyunca Anadolu'da Doğal Afetler ve Deprem Semineri, Istanbul 2001. İstanbul (2002) 41-49.

F. Ş. Arık, "Selçuklular Zamanında Anadolu'da Meydana Gelen Depremler". Tarih Araştırmaları Dergisi XVI/27 (1994) 13-32.

R. Arık - O. Arık, Tiles, Treasures of Anatolian Soil: Tiles of the Seljuk and Beylik Periods. İstanbul 2008.

R. Arık, Kubad Abad. İstanbul 2000.

S. S. Blair - J. Bloom, Art and Architecture of Islam 1250-1800. New Haven - London 1995.

C. E. Bosworth, The Later Ghaznavids: Splendour and Decay, the Dynasty in Afghanistan and Northern India 1040-1186. New York 1977.

C. E. Bosworth, The Ghaznavids - Their Empire in Afghanistan and Eastern Iran 994-1040. Beirut 1973.

E. G. Browne, A Literary History of Persia, vol. II. Bethseda - Maryland 1997.

R. Browning, The Byzantine Empire. London 1980.

C. Cahen, The Formation of Turkey: The Seljukid Sultanate of Rum: Eleventh to Fourteenth Century. Trans. \& Ed. P. M. Holt. Harlow - Essex 2001.

F. Daftary, The Isma'ilis: Their History and Doctrines. Cambridge 2007.

H. Darke, The Book of Government or Rules for Kings, the Siyar al-Muluk or Siyasat-nama of Nizam al-Mulk. London 1978.

J. E. DeJean, The Essence of Style: How the French Invented High Fashion, Fine Food, Chic Cafés, Style, Sophistication, and Glamour. New York - 
28

Duggan forth. a

Duggan forth. b

Duggan - Aygün 2015

Duggan 2009

Duggan 2006

Edbury 1994

Elmore 1999

Erdmann 1961

Ettinghausen - Graber 1994

Forkl 1993

Foss 1991

Foss 1985

Hillenbrand 1999

Kaymaz 2011

Köprülü 1992

Krueger 1993

Lloyd - Storm Rice 1958

Mardrus - Mathers 1996

Müller 1979

Özcan 2005

Ragheb 2002

Sauvaget 1994
London 2005.

T. M. P. Duggan, "Depictions of Communications on Some Late $12^{\text {th }}$ - Early $13^{\text {th }}$ C. Seljuk Mina'i-ware, Including "Heliographs" and the Possible Depiction of Cyphers for Mirror Messaging". 2016 [Forthcoming].

T. M. P. Duggan, "Taşdibi'ndeki Rum Selçuk Mânarı -The Rum Seljuk Mânar at Taşdibi". Uluslararası XVIII. Ortaçağ ve Türk Dönemi Kazıları ve Sanat Tarihi Araştırmaları Sempozyumu, Aydın, 22 ${ }^{\text {nd }}-25^{\text {th }}$ October 2014. Proceedings 2016 [forthcoming].

T. M. P. Duggan - Ç. A. Aygün, "The Medieval and Later Port of Myra /Stamira - Taşdibi". Eds. S. Ladstätter, F. Pirson - T. Schmidts, Byzas 19 Harbors and Harbor Cities in the Eastern Mediterranean from Antiquity to the Byzantine Period: Recent Discoveries and Current Approaches. İstanbul (2015) 245-269.

T. M. P. Duggan, "Diplomatic Shock and Awe: Moving, Sometimes Speaking Islamic Statues". Al-Masaq, Islam and the Medieval Mediterranean 21/3 (2009) 229-267.

T. M. P. Duggan, "The Motifs Employed on Rum Seljuk $13^{\text {th }}$ Century Eight Pointed Star Tiles from Antalya Province and Elsewhere in Anatolia: An Interpretation". Adalya IX (2006) 149-219.

P. W. Edbury, The Kingdom of Cyprus and the Crusades 1191-1374. Cambridge 1994.

G. Elmore, "The Book of the Fabulous Gryphon". The Journal of the Muhyiddin ibn 'Arabi Society XXV (1999) 62-87.

K. Erdmann, Das Anatolische Karavansaray des 13. Jahrhunderts Erster Teil. Berlin 1961.

R. Ettinghausen - O. Graber, The Art and Architecture of Islam, 650-1250. Yale 1994.

H. Forkl, Die Garten Des Islam. Stuttgart - London 1993.

C. Foss, "Beacons". ODB 1 (1991) 273-274.

C. Foss, Survey of Medieval Castles in Anatolia I: Kutahya. Oxford 1985.

C. Hillenbrand, The Crusades: Islamic Perspectives. Edinburgh 1999.

N. Kaymaz, Anadolu Selçuklularının Inhitatında idare Mekanizmasının Rolü. Ankara 2011.

M. F. Köprülü, The Seljuks of Anatolia: Their History and Culture According to Local Muslim Sources. Trans. \& Ed. G. Leiser. Salt Lake City 1992.

I. Krueger, Glass Mirrors in Medieval Times. Amsterdam 1993.

S. Lloyd - D. Storm Rice, Alanya ('Alā'iyya). London 1958.

J. C. Mardrus - P. Mathers, The Book of the Thousand Nights and One Night, vol. II. Trans. J. C. Mardrus - P. Mathers. London - New York 1996.

P. J. Müller, Arabische Minaturen. Geneva 1979.

K. Özcan, "Ortaçağda Anadolu'nun İdarî Coğrafyasına Bakış: Anadolu'da Selçuklu İdarî Birimleri - The View on the Administrative Geography of Anatolia in Medieval - The Administrative Units during Seljuk Period in Anatolia". Coğrafi Bilimler Dergisi 3/1 (2005) 73-99.

Y. Ragheb, Les Messagers Volants en terre d'Islam. Paris 2002.

J. Sauvaget, "Caravansérails Syriens du Moyen-Âge, I. Caravansérails Ayyūbides (env. 1125-1260 A.D.)". Ed. Anonymous, Studies by Jean Sauvaget on the Historical Geography and Topography of Syria Collected and Reprinted by F. Sezgin. Islamic Geography vol. 230. Frankfurt am Main (1994) 308-319. 
Savvides 1981

Serjeant 1972

Schimmel 2001

Schiltberger 1879

Schreiner 1977

Setton 1956

Silverstein 2007

Tudela 2005

Turan 1988

Usama 2008

Vakıf 1983

Verita 2007

Ward 2008

Watson 2004

Wilson 1996

Younis 2014

Yılmaz - Tuzcu 2010
A. G. C. Savvides, Byzantium in the Near East: its Relations with the Seljuk Sultanate of Rum in Asia Minor, the Armenians of Cilicia and the Mongols A.D. c. 1192-1237. Thessalonike 1981.

R. B. Serjeant, Islamic Textiles-Material for a History up to the Mongol Conquest. Beirut 1972.

A, Schimmel, As Through a Veil-Mystical Poetry in Islam. Oxford 2001.

J. Schiltberger, The Bondage and Travels of Johann Schiltberger (13961427). Trans. J. B. Telfer. London 1879.

P. Schreiner, Die Byzantenischen Kleinchroniken, 2. Teil - Historischer Kommentar. Vienna 1977.

K. M. Setton, "The Byzantine Background to the Italian Renaissance". Proceedings of the American Philosophical Societies 100/1 (1956) 1-76.

A. J. Silverstein, Postal Systems in the Pre-Modern Islamic World. Cambridge 2007.

B. Tudela, The Itinerary of Benjamin of Tudela (1907). Trans. \& Comment.: N. M. Adler. London 2005.

O. Turan, Türkiye Selçukluları Hakkında Resmi Vesikalar, Metin, Tercüme ve Araştırmalar. Ankara 1988.

Usama ibn Munqidh, The Book of Contemplation: Islam and the Crusades. Trans.: P. M. Cobb. London 2008.

Türkiye'de Vakıf Abideler ve Eski Eserler: Adana-Artvin, Ankara. Ankara 1983.

M. Verita, "Influence of the Islamic Tradition on the Chemistry and Technology of Venetian Glass". Ed. S. Carboni, Venice and the Islamic World 828-1797. New Haven - London (2007) 276-9.

G. W. R. Ward, The Grove Encyclopedia of Materials and Techniques in Art. Oxford 2008.

O. Watson, Ceramics From Islamic Lands- Kuwait National Museum-The Al-Sabah Collection. London 2004.

N. G. Wilson, Scholars of Byzantium. London 1996.

M. Younis, "The Seljūqs of Rum and the Ayyubids; Political Relations and Intermarriage, through Coinage". Ed. Anonymous, First International Congress of the Anatolian Monetary History and Numismatics. 25-28 February 2013, Proceedings. Antalya (2014) 703-714.

L. Yılmaz - K. Tuzcu, Antalya'da Türk Dönemi Kitabeleri. Harlem 2010. 